\title{
OBITUARIES
}

\section{Dr. B. L. Goodlet, O.B.E.}

THe death occurred on October 27 of Dr. Brian Laidlaw Goodlet, deputy chairman of the Brush Electrical Engineering Co., and, until recently, its managing diroctor.

Brian Goodlet was born in St. Petersburg in 1903 of British parents who had settled in Russia in the service of the Government, and was educated at the Imperial School in St. Petersburg. He escaped from Russia during the Revolution and received his further training with Vickers, Ltd., and MotropolitanVickers, first at the Attercliffe Works, Sheffield, studying in the Applied Science Department of the University of Sheffield, where he gained the associateship in eloctrical ongineoring, and then as a special trainee in the Trafford Park Works. In 1924 he was appointed to the staff in charge of the first Highvoltage Laboratory, and there he introduced to the Company high-frequency and impulse voltage testing of electrical products, and made important contributions to the study of transmission and bushing insulators, during which time he designed the second. High-voltage Laboratory equipped for a million volts. He also designed the very small high-voltage generator which the Metropolitan-Vickers Co. gave to the Cavendish Laboratory to assist $m e$ in the first attempts to accelorate particles to very high energy for transmutation experiments, and then designed the special high-voltage transformer of extremely small dimensions which was used by Cockeroft and Walton in their 1932 experiments. There were no other high-voltage transformers in those days which could have fitted into the small rooms of the Caven. dish Laboratory, and we owe Goodlet a great debt for these expert designs : without thom Britain might not have beon ahead of the large Ameriean laboratories.

It was through his contacts with the Cavendish Laboratory that he decided to take the Engineering Tripos in Cambridge, leaving Manchester at the age of twenty-seven with a generous grant from the Company. On his return to Trafford Park he made a detailed study of oxtra high-voltage turboalternators, and also wrote his classic paper on lightning.

In 1937 Goodlet was appointed to the chair of electrical engineering in Cape Town, but he returned to Britain in 1939 to take up the chair in Birmingham. He offered his services to the Admiralty, but, because of his former connexion with Russia, he was not accepted; so he applied to return to the still vacant chair in South Africa, where he immediately joined the South African naval work on the degaussing of ships in Cape Town Harbour, ultimately gaining the rank of commander in the South African Navy. After a short time he was sent to England to work with the Bitish Admiralty as chief scientist at Rosyth, where he made distinguished contributions to work on underwater explosions, before joining the Far East Naval Task Force in Ceylon under Lord Mountbatten. He was made O.B.E. for his war services. In 1946 he returned to Cape Town, where he built up a vigorous electrical engineering department with almost pitiable funds, gathering around. him several engineers from the Metropolitan-Vickers Co. and starting a lively research school; but this had searcely begun to bear fruit when he returned to England again in 1950, this time as deputy chief ongineer of the Atomic Energy Establishment at Harwoll. His text-book on basic electrotechnicsthe result of his post-war work in South Africa-has become well established in British universities for second-and third-year honours engineering students.

Goodlet began in Harwell with a small team, including Mr. R. V. Moore, to investigate in detail the feasibility of a power-producing nuclear reactor system, referred to as Pippa, using natural uranium. The team selected graphite as moderator, carbon dioxide as coolant gas and a vertical arrangement of fuel rods, and by 1952 all the main features of the design had been established: it was then handed over to the Production Division to produce Calder Hall. It is a tribute to Goodlet's engineering judg. ment that no major changes of design were necessary. (His paper, "Nuclear Reactors for Power Generation", to the Institution of Mechanical Engineers, was awarded the Thomas Hawksley Gold Medal.)

During 1952-56 he was the chairman of the Naval Education Advisory Committee of the Admiralty: the Director of the Naval Education Service advises me that he made an ideal chairman and was greatly respected by his colleagues. During Goodlet's period of office, the Committee advised on a number of important matters, including cadet entry into the Royal Navy, officer training, the technical training of junior ratings, the conditions of service of civilian teaching staff at the Royal Naval Colleges, the rohabilitation of the Dockyard Technical Colleges and the organization of facilities for informing the Service of modern developments in science and technology. His untiring interest and wise counsel in all aspects of naval education were of the utmost value to the Director of the Naval Education Service.

By 1956, Goodlet felt that his work at the Atornic Energy Research Establishment was finishəd, and he joined the Brush Electrical Co., Loughborough, as ehief engineer and director, later becoming its managing director. Mr. G. B. R. Feilden tells me that Goodlet was confronted by a series of major breakdowns of 30-MW. double-rotation turbines which had been designed before Goodlet joined the Company. The breakdowns were caused by vibration, and the solution to the problem required the evolution of entirely now measuring techniques: Goodlet was responsible for solving this problem, which was fortunately achieved successfully, largely due to his own persoverance, shortly before his death. He submitted his published work to Cambridge and was awarded the Sc.D. in 1958.

Perseverance and thoroughness characterized all his work: like the great American engineer, Charles Proteus Steinmetz, he was never satisfied until he understood the fundamentals of any problem which confronted him, and he was fondly nicknamed 'Prot' by his elosest friends because of this similarity. He invariably wrote out the basic facts and deduced the solution in beautiful handwriting, and his notebooks were a joy to peruse. His perseverance was equally manifest in his hobbies, and he enjoyed going up Table Mountain the hardest way. He was extremely interested in military strategy and it was fascinating to hear him quote Napoleon's campaigns; he even wrote a mathematical paper on the ballistics of 
weapons used in classical times. I was present when Rutherford, returning from the British Association meoting in South Africa, recited the exploits of Cetywayo; Goodlet, to Rutherford's great delight, continued the story with intimate details of the part played by the Zulu's lieutenants.

Goodlet is survived by a widow, two sons, and two daughters.

T. E. Alimone

\section{Dr. A. K. Das}

INDIA lost a meteorologist of note and a leading astronomer of this century with the death on February 18, 1961, of Anil Kumar Das. He was best known for his work at Kodaikanal Astrophysical Observatory, of which he was the head for fourteen years. At the time of his death, however, he was acting temporarily as director of the Nazamiah Observatory, Hyderabad, and as professor of astronomy at Osmania University. But although best known for his astrophysical researches, Dr. Das published a number of papers on purely meteorological topies, mainly during the early part of his thirty-years service in the India Meteorological Department.
After completing his education to postgraduate level in India, Das continued his studies in Paris under Fabry and later also worked with Max Born and Augenheister. He returned to India in 1930 to commence his meteorological work, but in 1934 he went to England to study the temperature of the Sun by spectro-photographic means at the Solar Physics Observatory, Cambridge. This virtually marks the beginning of his career in astronomy. His many papers on solar physics thereafter appeared at regular intervals almost up to the date of his death.

Das had the intuitive foresight, great energy and determination of the great research worker, but he was also an administrator of considerable ability. Indeed, his greatest achievements probably lie in the improvements he introduced at Kodaikanal, by the installation of new equipment and the initiation of new fields of research. Largely thanks to Das, this Observatory is now earrying out researches and making observations, using the finest equipment, in many branches of geophysics and solar physics. It is a pity that he could not live long enough to fulfil his last ambition to work with his new instruments during the last years of his life.

\section{NEWS and VIEWS}

Botany in University College, Dublin :

\section{Prof. J. Doyle}

Prof. Josepr Doxle has retired from the chair of botany in University College, Dublin, after nearly fifty years service. He entered the College on a mathematical scholarship; later he became interested in biology through the pathway of medicine. Following a period of postgraduate research, part of which was spent in Germany, he was appointed assistant in biology in 1913; at this time, he and two others comprised the staff of the Biology Department. In 1924 he was appointed professor of botany, and undertook the development of the first Department of Botany in the College. His main research interest is represented by a long series of papers on conifer embryology, on which subject he is internationally recognized as an authority. He was awarded the Boyle Medal of the Royal Dublin Society in recognition of this work. The degree of D.Sc. was conferred on him in 1930. At the Dublin meeting of the British Association for the Advancement of Science in 1957, he was president of Section K (Botany). In addition to developing the Department of Botany, Prof. Doyle rendered distinguished administrative service to his College. As dean of the Faculty of Science he showed considerable organizing power; for many years he was a member of the Governing Body of the College and of its Finance Committee. He has helped greatly in furthering the scientific and cultural life of Dublin. $\mathrm{He}$ is a member of the Council of the Royal Dublin Society, secretary of the Royal Irish Academy, chairman of the Praegar Committee for Field Natural History, and a trustee of the National Library of Ireland. Recently he has been actively engaged in planning new Science Buildings for University College, Dublin. His many interests will ensure for him rewarding occupation in his retirement.

\section{Prof. Phyllis M. Clinch}

Dr. Phyllis M. Cinsch has been appointed to succeed Prof. J. Doyle. Dr. Clinch, in fact, majored in chemistry in University College, Dublin, with first-class honours and first place at her primary degree, but, botany being her second subject, she took an immediate interest in plant biochemistry and her earlier research was done in the Department of Botany on problems of seasonal metabolic changes in conifers. In this and in all her subsequent work her early intensive training in basic chemistry proved a most valuable asset. After a period of study under Prof. V. H. Blackman in the Imperial College and Prof. Guilliermond in Paris, she was appointed senior research assistant in plant virus diseases in the Department of Plant Pathology, University College. Dublin. Here she played a major part in the team that produced so much important work on plant viruses, especially the analyses of viruses affecting the potato plent. The value of the work from this Irish School is too well known to need comment here; suffice it to say that Dr. Clinch's share in it has gained her a well-merited international reputation in the plant virus world. In 1950 she accepted an invitation to join the staff of the Botany Department. University College, as senior lecturer with the primary purpose of developing courses and research in plant biochemistry and physiology along modern lines. The very successful organization of this entailed, unfortunately, a temporary break in her work on viruses. The break, however, was only temporary, and in recent years she has initiated a programme of research into the biochemical and physiological effects of virus infection on the metabolism of the infected plants themselves. It is to be hoped that the administrative and other duties which will now naturally fall on her as head of a department will not unduly hamper progress in this promising line of research. 